\title{
Jenis-Jenis Teripang (Holothuroidae) di Perairan Kampung Auki Distrik Padaido Kabupaten Biak Numfor, Papua
}

\author{
NIA CHRISTINE PALLO*1 DAN NIKKI LEWAHERILLA ${ }^{2}$ \\ ${ }^{* 1}$ Jurusan Biologi FMIPA Universitas Cenderawasih, Jayapura-Papua \\ ${ }^{2}$ BPPT Pertanian Papua
}

Diterima: tanggal 15 Oktober 2010 - Disetujui: tanggal 13 Februari 2011

(c) 2011 Jurusan Biologi FMIPA Universitas Cenderawasih

\begin{abstract}
Sea cucumber is one of important commodity in Papua. Beside play role as protein source, sea cucumber also important cosmetic ingredient. Despite Papua has rich in sea natural resources, until now still lack of information on diversity of sea cucumber in Papua, therefore, this study aim to identify the species and diversity of sea cucumber of one of sea cucumber in sea water of Auki island. The study has conducted during March-April 2010. Transect line was used in this study. Data were collected from 3 station, five transect lines were placed at each station. Abiotic factors such as salinity, temperature and $\mathrm{pH}$ of sea cucumber habitat were also collected during the study. Diversity index was calculated by using Shannon-Wienner formula. It was found that index of diversity sea cucumber $(\mathrm{H})$ at 0.23 . Sea cucumber species found were Actinopyga lecanora, Actinopyga miliaris, Bohadschia similis, Bohadschia marmorata, Bohadschia vitiensis, Holothuria scabra, Holothuria scabra var versicolor, Holothuria atra, Holothuria argus dan Holothuria coluber.
\end{abstract}

Key words: Species diversity, Sea cucumber commodity, Auki Island.

\section{PENDAHULUAN}

Teripang merupakan salah satu anggota hewan berkulit duri (Echinodermata, Holothuroidae), atau dikenal sebagai ketimun laut (sea cucumber) karena bentuknya seperti ketimun. Teripang umumnya dijumpai di perairan dangkal yang ditumbuhi lamun, walaupun dapat juga ditemukan di hamparan pasir atau rataan terumbu karang di perairan laut yang tenang (Romimohtanto \& Juwana, 2004). Kelompok hewan ini, merupakan salah satu organisme dari sekian banyak makhluk hidup yang mempunyai peranan penting dalam sistem perairan pantai

*Alamat Korespondensi: Jurusan Biologi FMIPA, Jln. Kamp Wolker, Kampus Baru UNCEN-WAENA, Jayapura Papua. 99358, Telp. (0967) 572116. email: nia_pallo@yahoo.com
(Chenelot et al., 2006).

Ekhinodermata merupakan salah satu komponen penting dalam keragaman fauna di daerah terumbu karang. Hal ini karena terumbu karang berperan sebagai tempat berlindung dan sumber pakan bagi fauna ekhinodermata. Secara ekologi fauna ekhinodermata berperan sangat penting dalam ekosistem terumbu karang, terutama dalam rantai makanan (food chain), karena biota tersebut umumnya sebagai pemakan detritus dan predator(Yusron, 2006).

Menurut Sutamin (1993), pada perairan Indonesia terdapat sekitar 60 jenis teripang, tetapi baru sekitar 9 jenis yang telah diusahakan dan dimanfaatkan sebagai makanan yang mempunyai nilai ekonomi tinggi. Teripang merupakan salah satu komoditi hasil perikanan yang potensial untuk dimanfaatkan sebagai bahan pangan berkadar protein tinggi (Anonimous, 2003). Teripang selain sebagai sumber protein tinggi (50- 
$60 \%$ ), juga dimanfaatkan dalam bidang industri obat-obatan dan kosmetik di beberapa negara maju. Menurut Yusron \& Widianwari (2004) di daerah tropis jenis-jenis teripang yang bernilai komersial meliputi genus Actinopyga, Bohadschia, Holothuria, Stichopus dan Thelenota.

Teripang mempunyai nilai ekonomis tinggi di pasaran, keberadaannya di kawasan Padaido tersebar hampir seluruh perairan pesisir dan peluang untuk pengembangan budidaya perikanan sebagai sarana mata pencaharian alternatif masyarakat sangat memungkinkan (Laksono et al., 2001).

Teripang dapat ditemukan hampir di seluruh perairan pantai, mulai dari daerah pasang surut yang dangkal sampai perairan yang lebih dalam. Untuk hidupnya, teripang lebih menyukai perairan yang jernih dan air yang relatif tenang. Umumnya, masing-masing jenis memiliki habitat yang spesifik, misalnya teripang putih banyak ditemukan di daerah yang berpasir atau pasir bercampur lumpur di kedalaman 1-40 m. Teripang putih juga sering ditemukan di perairan yang dangkal dan banyak ditumbuhi ilalang laut (lamun). Teripang koro (Microthede nobelis) dan teripang pandan (Thelonota ananas) banyak di temukan di perairan yang lebih dalam.

Penyebaran teripang di Indonesia sangat luas di beberapa daerah penyebarannya antara lain meliputi perairan pantai Madura, Jawa Timur, Bali, Lombok, Aceh, Bengkulu, Riau dan sekitarnya, Belintung, Kalimantan (bagian barat, timur dan selatan), Sulawesi, Maluku, Timor dan Kepulauan Seribu (Martoyo et al., 2007).

Di Kepulauan Padaido, yang merupakan gugusan pulau di sebelah utara Papua merupakan salah satu kawasan yang memiliki keragaman hayati laut yang sangat tinggi (Bengen et al., 2005). Perairan Padaido diperkirakan memiliki sekitar 95 jenis koral dan 155 jenis ikan, antara lain berbagai hiu karang dan gurita serta berbagai kekayaan lainnya. Kekayaan biologi lain yang ada di kepulauan ini antara lain 48 jenis pohon, 26 jenis burung, 14 jenis reptil dan 7 jenis mamalia (Anomimous, 2008).

Kepulauan Padaido ditetapkan sebagai kawasan taman wisata alam laut melalui Surat
Keputusan (SK) Menteri Kelautan No.91/kptsIV/97. Kekayaan dan keragaman sumberdaya pesisir dan laut tersebut menjadikan kawasan Kepulauan Padaido sebagai daerah pengembangan pariwisata dan perikanan, yang juga merupakan lokasi kegiatan COREMAP sejak tahun 1998 (Lewaherilla et al., 2009).

Seiring dengan perjalanan waktu muncul fenomena pemanfaatan sumberdaya perikanan secara eksploritatif (pemanfaatan tidak ramah lingkungan). Hal ini berpengaruh pada perencanaan sumberdaya biota ekonomis pada pesisir di Pulau Padaido, dengan demikian perhatian terhadap kerusakan dan pertahanan keragaman hayati harus dilakukan. Berdasarkan pemasalahan tersebut dilakukan inventarisasi jenis-jenis teripang di Perairan Pulau Auki Distrik Padaido Kabupaten Biak Numfor.

\section{METODE PENELITIAN}

\section{Waktu dan Tempat Penelitian}

Penelitian ini dilaksanakan selama enam bulan dari bulan Januari hingga bulan Juni 2010 . Pengambilan data dilakukan di Perairan Pulau Auki Distrik Padaido Kabupaten Biak Numfor (gambar 1), di Papua.

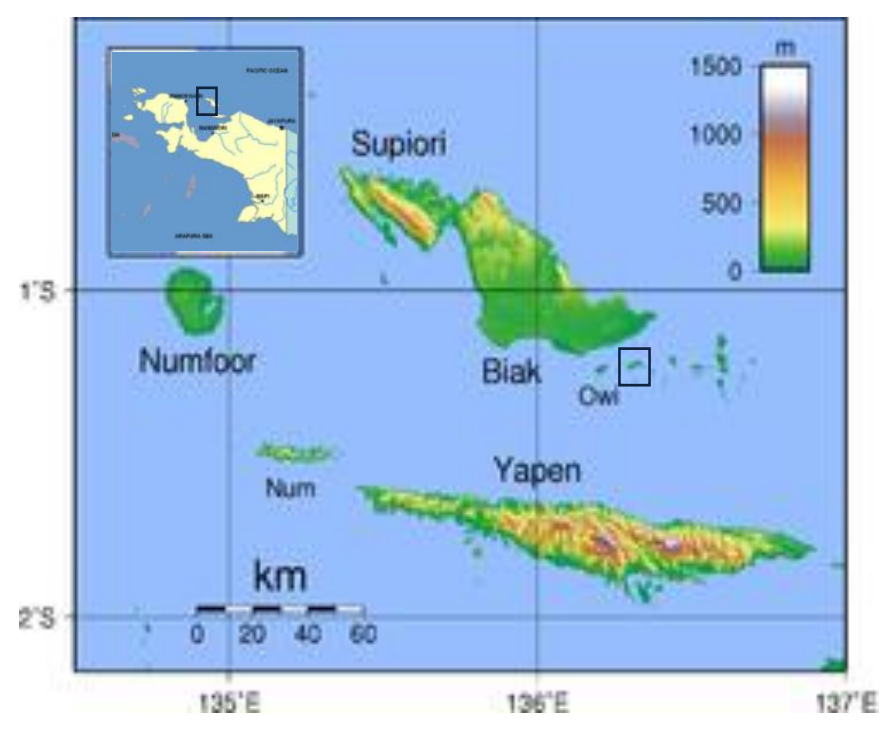

Gambar 1. Lokasi penelitian. 


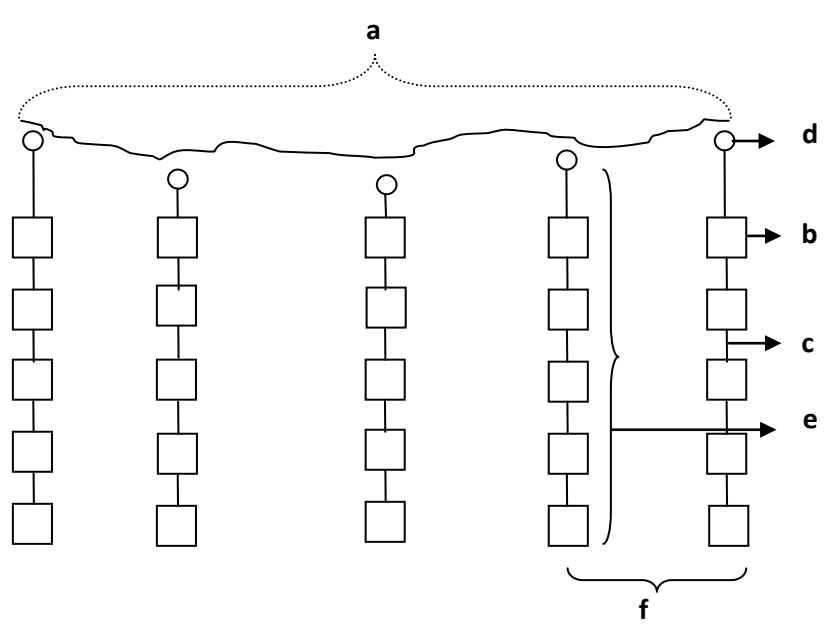

Gambar 2. Skema plot pengambilan sampel. a. garis pantai, b. plot berukuran 10x10 m., c. jarak antara plot $10 \mathrm{~m}$. , d. titik transek, e. panjang transek $100 \mathrm{~m} ., \mathrm{f}$. jarak antara transek $50 \mathrm{~m}$.

\section{Metode Penelitian}

Metode yang digunakan untuk menentukan area pengambilan contoh (sampel) dilakukan dengan cara survey (snorkeling)pada kedalaman 1$5 \mathrm{~m}$ pada saat air mengalami pasang, penentuan lokasi sebanyak 3 stasiun dan peletakan transek dilakukan ke arah laut (lepas pantai) sepanjang $100 \mathrm{~m}$. Setiap stasiun dibuat 5 titik transek dengan jarak antara transek $10 \mathrm{~m}$ (gambar 2).

Pemilihan lokasi pengamatan berdasarkan hasil wawancara dengan tokoh masyarakat, nelayan, dan survey awal di lapangan. Dengan berbagai pertimbangan dipilih stasiun pengamatan yang meliputi 3 titik stasiun, yaitu: I. Daerah kawasan sasi bagi masyarakat. Masyarakat tidak diperbolehkan mengambil apapun termasuk hasil laut, kecuali jika telah datang musim panen bagi nelayan (waktu ditentukan berdasarkan kesepakatan adat masyarakat setempat). II. Daerah kawasan bebas bagi masyarakat. Masyarakat diperbolehkan mengambil materi untuk kebutuhan masyarakat sehari-hari, III. Daerah dengan topografi ujung tanjung (Yariyar) yang merupakan daerah habitat teripang dan tempat penangkapan ikan para nelayan. Sebagian masyarakat sulit menjangkau lokasi tersebut.

Secara geografis, lokasi stasiun I terletak pada titik koordinat $01^{\circ} 13^{\prime} 42,7^{\prime \prime}$ LS dan $136^{\circ} 20^{\prime} 27,5^{\prime \prime}$ BT. Stasiun II terletak pada titik koordinat $\quad 01^{\circ} 13^{\prime} 40,0^{\prime \prime} \mathrm{LS}$ dan $136^{\circ} 19^{\prime} 56,6^{\prime \prime} \mathrm{BT}$, sedangkan stasiun III terletak pada titik koordinat $01^{\circ} 14^{\prime} 05,7^{\prime \prime}$ LS dan $136^{\circ} 20^{\prime} 40,4^{\prime \prime}$ BT. Kondisi ekologi yang diukur berdasarkan atas faktor lingkungan menunjukkan suhu dan $\mathrm{pH}$ yang beragam untuk setiap stasium pengamatan (Tabel 1).

Tabel 1. Hasil pengukuran faktor lingkungan di perairan Pulau Auki.

\begin{tabular}{lccc}
\hline Lokasi & $\begin{array}{c}\text { Suhu } \\
\left({ }^{\circ} \mathrm{C}\right)\end{array}$ & $\begin{array}{c}\text { Salinitas } \\
(\%)\end{array}$ & $\mathrm{pH}$ \\
\hline Stasiun I & 23 & 31 & 7,5 \\
Stasiun II & 22 & 31 & 10 \\
Stasiun III & 25 & 30 & 8,6
\end{tabular}

Untuk menghitung indeks keragaman dari 3 stasiun pengamatan tersebut digunakan indeks keragaman Shannon-Wienner (Fachrul, 2000).

$$
\mathrm{H}^{\prime}=-\sum \text { pi In } \rho \text { i atau } \mathrm{H}^{\prime}=-\sum\left[\frac{n_{i}}{N}\right] \log \left[\frac{n_{i}}{N}\right]
$$

Dimana:

$\mathrm{H}^{\prime}=$ Indeks keragaman

$\mathrm{n}_{\mathrm{i}}=$ Jumlah individu satu jenis

$N=$ Jumlah individu semua jenis

Berdasarkan nilai indeks tersebut, dapat ditentukan keragaman jenis sebagai berikut:

a. Nilai $\mathrm{H}^{\prime}>3$ menunjukkan bahwa keragaman jenis pada suatu transek adalah tinggi.

b. Nilai $\mathrm{H}^{\prime} 1 \leq \mathrm{H}^{\prime} \leq 3$ menunjukan bahwa keragaman jenis pada suatu transek sedang.

c. Nilai $\mathrm{H}^{\prime}<1$ menunjukan bahwa keragaman jenis pada suatu transek adalah rendah.

\section{HASIL DAN PEMBAHASAN}

\section{Keragaman Jenis Teripang}

Berdasarkan hasil penelitian yang dilakukan di perairan Pulau Auki ditemukan 10 jenis yaitu pada stasiun 1 sebanyak 3 jenis di dominansi oleh Holothuria scabra, stasiun 2 sebanyak 1 jenis di dominansi oleh Holothuria atra dan stasiun 3 sebanyak 7 jenis didominansi oleh Bohadschia similis(tabel 2). Hasil ini mirip dengan pengamatan yang dilakukan oleh Yusron (2004) di Pai, 
Kepulauan Padaido. Yusron (2004) menemukan bahwa kawasan ini juga didominasi oleh jenis Holothuria scabra dan $H$. atra. Namun dari hasil pengamatan Yusron (2004) ditemukan jenis teripang dari genus Aspidochirotida. Jenis dari genus ini sebagian besar hidup pada daerah pantai yang jernih. Selanjutnya Hyman dalam Yusron (2004) mengemukakan bahwa daerah Indo-Pasifik bagian barat, merupakan daerah yang kaya akan jenis teripang.

Hasil pengamatan ini menunjukkan bahwa di kawasan pantai perairan Kampung Auki masih dijumpai jenis teripang yang cukup tinggi, walaupun jika dilihat dari keberadaan penyebarannya sudah sangat kurang. Jenis yang dijumpai masih melimpah adalah Bohadschia similis dan $H$. atra., yang masing-masing dijumpai sekitar 39 dan 29 individu. Hal ini karena kedua jenis tersebut kurang diminati oleh masyarakat untuk dikonsumsi. Dari 3 stasiun pengamatan, diketahui bahwa keberadaan teripang di stasiun pengamatan II sangat kurang. Rendahnya tingkat jenis dan jumlah individu dari masing-masing jenis disebabkan karena tingkat perburuan masyarakat untuk kepentingan kebutuhan konsumsi sehari-hari dan sebagian lagi

Tabel 2. Distribusi teripang pada setiap stasiun

\begin{tabular}{|c|c|c|c|c|c|}
\hline \multirow[t]{2}{*}{ No } & \multirow[t]{2}{*}{ Jenis Teripang } & \multicolumn{3}{|c|}{ Stasiun } & \multirow{2}{*}{$\begin{array}{l}\text { Total } \\
\text { Ind. }\end{array}$} \\
\hline & & I & II & III & \\
\hline 1. & Actinopyga lecanora & 1 & - & - & 1 \\
\hline 2. & A. miliaris & - & - & 1 & 1 \\
\hline 3. & Bohadschia similis & - & - & 39 & 39 \\
\hline 4. & B. marmorata & - & - & 4 & 4 \\
\hline 5. & B. vitiensis & - & - & 2 & 2 \\
\hline 6. & Holothuria scabra & 6 & - & 7 & 13 \\
\hline 7. & $\begin{array}{l}\text { H. scabra var } \\
\text { versicolor }\end{array}$ & 4 & - & - & 4 \\
\hline 8. & H. atra & - & 24 & - & 24 \\
\hline 9. & H. argus & - & - & 1 & 1 \\
\hline \multirow[t]{2}{*}{10.} & H. coluber & - & - & 2 & 2 \\
\hline & Total individu & 11 & 24 & 56 & 99 \\
\hline
\end{tabular}

dipasarkan.

Daerah yang tergolong rendah (stasiun II) merupakan daerah bebas bagi nelayan dan

Tabel 3. Jenis teripang yang dijumpai pada lokasi penelitian yang mempunyai habitat lamun dengan berbagai macam substrat.

\begin{tabular}{lll}
\hline No & \multicolumn{1}{c}{ Jenis } & \multicolumn{1}{c}{ Substrat } \\
\hline 1. Actinopyga lecanora & Pasir + lumpur berpasir \\
2. A. miliaris & Berpasir \\
3. Bohadschia similis & Pasir + Pasir Berkarang \\
4. B. marmorata & Berpasir \\
5. B. vitiensis & Berpasir \\
6. Holothuria scabra & Pasir + pasir Berlumpur \\
7. H. scabra var versicolor & Berpasir \\
8. H. atra & Pasir + Lumpur Berpasir \\
9. H. argus & Berpasir \\
10. H. coluber & Pasir berkarang \\
\hline
\end{tabular}

Tabel 4. Nilai indeks keragaman dari ketiga lokasi stasiun pengamatan teripang.

\begin{tabular}{clcc}
\hline Stasiun & \multicolumn{1}{c}{ Jenis } & Jumlah & $\mathrm{H}^{\prime}$ \\
\hline \multirow{4}{*}{ I $\quad$ Actinopyga lecanora } & 1 & 0,36 \\
& Holothuria scabra & 7 & \\
& Holothuria scabra var & 4 & \\
versicolor & & \\
II $\quad$ Holothuria atra & 11 & \\
\multirow{4}{*}{ III $\quad$ Individu } & 24 & 0 \\
& Bohadschia similis & 39 & 0,42 \\
& Bohadschia marmorata & 4 & \\
& Bohadschia vitiensis & 2 & \\
& Actinopyga miliaris & 1 & \\
& Holothuria argus & 1 & \\
& Holothuria scabra & 7 & \\
& Holothuria coluber & 2 & \\
\hline
\end{tabular}


masyarakat sekitar, bebas untuk mengakses wilayah tersebut. Bahkan diketahui bahwa hanya terdapat 1 jenis teripang yang masih tersisa, yakni H. atra. Lain halnya dengan stasiun pengamatan I, yang merupakan daerah sasi bagi masyarakat setempat. Daerah sasi merupakan daerah dimana masyarakat mampu mengatur pemanfaatan wilayah untuk kebutuhan sehari-hari. Wilayah ini akan tertutup bagi kepentingan umum pada periode tertentu. Namun pada saat tertentu, akan dibuka untuk umum dan masyarakat dapat mengambil atau memanfaatkan semua sumber daya yang ada. Hal ini karena masyarakat terlibat dengan keberadaan aturan "sasi" yang diatur oleh tetua adat bersama masyarakat setempat.

Jenis-jenis teripang yang ada di wilayah stasiun pengamatan I saat dilakukan pengamatan diketahui mempunyai keragaman jenis yang cukup rendah. Hanya diketahui terdapat 3 jenis teripang, masing-masing Actinopyga lecanora, Holothuria scabra, dan $H$. scabra var versicolor. Hasil ini berkaitan dengan beberapa bulan sebelumnya, wilayah ini telah dibuka untuk masyarakat oleh tetua adat sebagai bagian dari pemanfaatan sumber daya alam untuk kepentingan masyarakat setempat. Sehingga masyarakat "memanen" sumber daya untuk kebutuhan mereka.

Pada stasiun III, walaupun tergolong kawasan bebas aktivitas untuk masyarakat, tetapi mempunyai keragaman jenis yang lebih tinggi. Terbukti diketahui terdapat 7 jenis teripang dengan jumlah kerapatan tertinggi diantara ketiga stasiun yang diamati. Tingginya keragaman teripang ini disebabkan karena kawasan ini merupakan daerah yang sulit terjangkau bagi masyarakat umum. Lokasi yang merupakan daerah tanjung menyulitkan masyarakat untuk datang dan memanfaatkan sumber daya wilayah yang ada. Masyarakat lebih senang untuk memperoleh sumber kebutuhan sehari-hari, termasuk teripang pada stasiun II atau daerah lain yang mudah dijangkau.

Hasil pengamatan yang ditunjukkan oleh Yusron (2006) di perairan teluk saleh, Sumbawa, ditemukan 9 jenis Holothuroidae, yang didominasi oleh teripang pasir (Holothuria scabra), Yusron \& Widianwari (2004) mengidentifikasi setidaknya ada 14 jenis teripang di Kepulauan Kei Besar, Maluku Tenggara, sedangkan Yusron \& Susetiono (2010) menemukan 4 jenis yang termasuk dalam Holothuroidae di Maluku Utara.

Teripang mempunyai habitat hidup yang lebih menyukai pasir. Dari hasil pengamatan nampak bahwa pantai di Kampung Auki lebih didominasi oleh pasir (tabel 3). Menurut Yusron (2003), Yusron \& Widianwari (2004) dan Yusron (2006) jenis-jenis Holothuria scabra yang sering dijumpai di sebagian besar perairan Indonesia ditemukan melimpah pada lokasi berpasir yang banyak ditumbuhi lamun dan rumput laut. Hal ini karena habitat tersebut cocok untuk kehidupan teripang pasir pada waktu air surut, membenamkan diri di dalam pasir dan butuh perlindungan dari sinar matahari.

Hasil analisa menunjukkan bahwa keragaman jenis teripang di perairan Pulau Auki Distrik Padaido Kabupaten Biak Numfor berdasarkan Indeks Keanekaragaman Shanon Wienner $\left(\mathrm{H}^{\prime}\right)$ sebesar 0.22, hal ini menunjukkan bahwa keanekaragaman jenis pada suatu stasiun adalah sedikit atau rendah.

Keragaman jenis pada stasiun I, pada daerah sasi mempunyai indeks keanekaragaman adalah 0,38 . Menurut Fachrul (2007) $\mathrm{H}^{\prime}<1$ menunjukkan bahwa keragaman jenis pada suatu transek adalah rendah. Pada stasiun ini, ditemukan 3 jenis teripang yang lebih didominasi oleh teripang pasir atau sering dikenal dengan teripang gosok abu Holothuria scabra.

Keragaman jenis teripang pada stasiun II , di depan Goa Kubendi mempunyai indeks keragaman $=0$ (nol). Menurut Fachrul (2007) $\mathrm{H}^{\prime}<1$ menujukkan bahwa keragaman jenis pada suatu transek adalah rendah. Pada stasiun 2 ini hanya ditemukan satu jenis teripang yaitu teripang darah H. atra.

Keragaman jenis teripang di stasiun III atau sering di kenal dengan nama Yariyar mempunyai indeks keanekaragaman Shannon wienner $=0,42$. Sepertihalnya di stasiun lain, Menurut Fachrul (2007) keragaman jenis teripang ini termasuk rendah, namun lebih tinggi dibanding dengan stasiun lain sehingga keberadaannya lebih baik. 

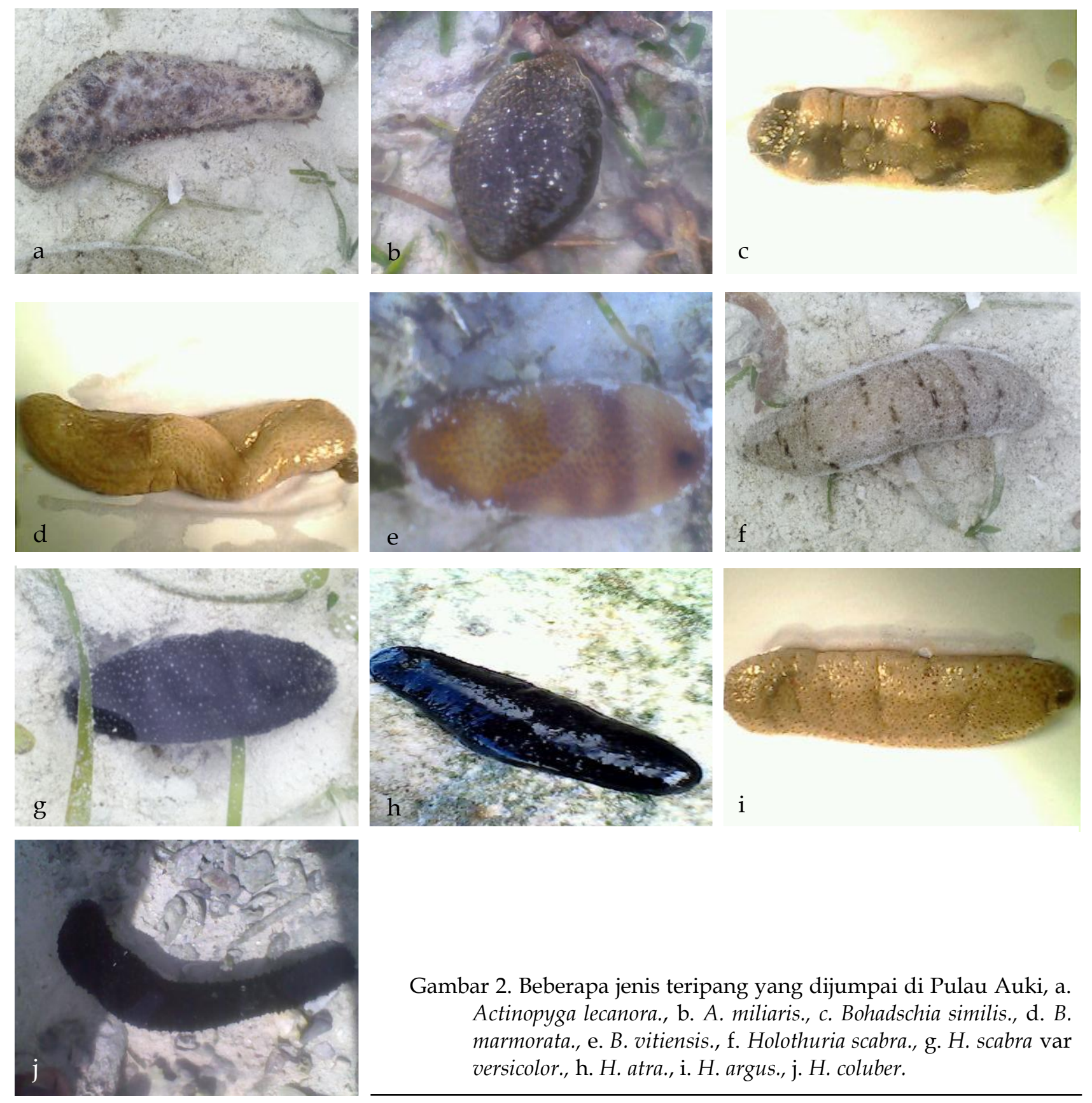

Gambar 2. Beberapa jenis teripang yang dijumpai di Pulau Auki, a. Actinopyga lecanora., b. A. miliaris., c. Bohadschia similis., d. B. marmorata., e. B. vitiensis., f. Holothuria scabra., g. H. scabra var versicolor., h. H. atra., i. H. argus., j. H. coluber.

Tinggi rendahnya indeks keragaman tergantung dari berapa banyak dan ragamnya suatu jenis teripang. Dengan diketahui nilai indeks keragaman ini, maka kawasan pantai Kampung Auki mempunyai keragaman rendah.

\section{Karakteristik umum jenis teripang}

Actinopyga lecanora, mempunyai bentuk tubuh oval, kasar, melengkung bagian sisi atas, kempes bagian bawah, tubuhnya berwarna coklat- hitam. Sebagian besar hidup di batu karang dan di dalam area yang dinaungi lamun, pada kedalaman 0-10 m. Panjang tubuhnya bisa mencapai $25 \mathrm{~cm}$ dengan rata-rata bobot beratnya $0,4 \mathrm{~kg}$.

A. miliaris, bentuk tubuhnya oval dan dengan penampang melintang bulat, seluruh permukaan tubuh mulus dan hitam. Ditemukan di perairan dangkal, namun masih sering dijumpai 
pada kedalaman 1-15 $\mathrm{m}$, dengan bobot berat ratarata berat $0,4 \mathrm{~kg}$.

Bohadschia similis, bentuk tubuhnya bulat panjang dan sedikit pipih bagian bawah. Bagian bawah halus, hitam dengan tanda coklat, umumnya berukuran 8-10 cm. Hidup di daerah tepi pantai, pada kedalaman 1-3 m., dengan habitat pasir dan pasir berkarang.

B. marmorata, bentuk badan bulat panjang, seluruh bagian tubuh apabila diraba tidak kasar, bila di tekan badannya akan mengeluarkan cairan warna putih, warna tubuh umumnya coklat dan bercak-bercak hitam dipunggungnya, bagian perutnya berwarna putih. Panjang teripang yang dijumpai $\pm 30 \mathrm{~cm}$. Daerah penyebaran pada dasar perairan yang bersubstrat karang berpasir, hidup pada kedalaman $\pm 60 \mathrm{~cm}$.

B. vitiensis, bentuk tubuh silindris, warna coklat sampei coklat kehitaman, hidup di pesisir dan rataan terumbu karang, hidup pada kedalaman 0-20 m, tetapi kebanyakan hidup pada kedalaman 1-10 m. Ukuran tubuhnya umumnya $14-18 \mathrm{~cm}$.

Holothuria scabra, bentuk tubuh bulat memanjang, warna kecoklatan, terdapat sekatsekat yang melintang berwarna putih, diantara sekat-sekat tersebut terdapat garis-garis hitam pada bagian punggung, mempunyai ukuran umumnya $22 \mathrm{~cm}$. Daerah penyebarannya di daerah pesisir dan rataan terumbu karang serta tumbuhan lamun.

H. scabra var versicolor, bentuk tubuh silindris, habitatnya ada yang hidup di terumbu karang dan pecahan karang, berpasir dan lamun. Hidup pada kedalaman 0-30 m., rata-rata berat tubuhnya $1,1 \mathrm{~kg}$, tebal tubuhnya $7 \mathrm{~mm}$. Umumnya tubuh berukuran $12-16 \mathrm{~cm}$.

$H$. atra, bentuk tubuhnya bulat panjang dan bagian bawah agak pipih, seluruh bagian tubuhnya terdapat bintik-bintik halus dan berwarna hitam. Jenis ini menyukai perairan yang berkarang atau berpasir. Panjang tubuh teripang $\pm 8-15 \mathrm{~cm}$., hidup pada kedalaman 0-20 m, tetapi kebanyakan hidup pada kedalaman 0-5 m. Ditemukan di daerah yang perairannya dangkal.

$H$. argus, bentuk silindris sedikit runcing pada salah satu ujungnya, Sisi bagian atas lembut, warna coklat muda dan terdapat bintik-bintik hitam. Ditemukan di terumbu karang dan di atas pasir putih, sebagian besar teripang ini hidup pada kedalaman1-10 cm. Panjang tubuhnya bisa mencapai $36 \mathrm{~cm}$.

H. coluber, bentuk tubuh kurus tidak beraturan, warnanya coklat, ukuran umumnya 18$22 \mathrm{~cm}$. Hidup di daerah terumbu karang, pada kedalaman 0-15 m, sebagian besar dijumpai pada kedalaman $0,5 \mathrm{~m}$.

\section{Pemanfaatan Teripang oleh Masyarakat}

Pemanfaatan teripang bagi masyarakat dalam kehidupan sehari-hari sebagai sumber makanan, jenis-jenis teripang yang di konsumsi oleh masyarakat yaitu H. scabra, B. marmorata, dan $H$. nobilis dan ada satu jenis teripang yang di gunakan masyarakat untuk pengusir obat-obatan (guna-guna) dan menghilangkan biji nasi yaitu jenis teripang darah (H. atra).

Teripang selain dimakan secara langsung, juga dijual dalam bentuk segar dan olahan kering. Olahan kering ini pemasarannya langsung kepada pedagang. Beberapa cara masyarakat mengolah teripang sebagai berikut.

1. Untuk dikonsumsi secara langsung

a. Teripang yang diambil dari laut dicuci sampei bersih dengan air laut

b. Kemudian teripang tersebut di bersihkan isi perutnya sampei bersih, dengan cara meramas/menekan isi perutnya hingga isi perutnya keluar

c. Setelah itu dicuci bersih dan dimasak

2. Produk olahan teripang kering
a. Teripang diambil dari laut
b. Dibersihkan dengan air hingga bersih, dikeluarkan isi perutnya
c. Kemudian dicuci lagi hingga bersih
d. Setelah itu di asar di atas tungku hingga kering
e. Hingga kering dan siap dipasarkan.

\section{Usaha Konservasi Teripang di Auki}

Jika diamati dari jenis dan penyebarannya, jenis-jenis teripang di kawasan pantai Kampung Auki menunjukkan perbedaan yang sangat tinggi dari ketiga stasiun penelitian. Oleh karena itu, 
dalam usaha untuk mempertahankan keragaman dan keberadaan teripang secara umum di daerah ini harus memperhatikan lokasi dan kesepakatan dari berbagai pihak.

Pihak-pihak yang dianggap penting dalam memutuskan kebijakan akan berpengaruh terhadap kelangsungan hidup dan mempertahankan tingkat keragaman jenis teripang. Bukan hanya tugas pemerintah, tetapi kebijakan tingkat kampung yang mempunyai nilai budaya kemasyarakatan tinggi akan sangat membatu. Kesepakatan tetua adat dan budaya masyarakat harus ditegakkan dengan baik. Khususnya mengenai sasi, harus diatur sesuai dengan kebutuhan masyarakat dan disesuaikan dengan kepentingan konservasi. Jika tingkat produktivitas rendah, maka tidak perlu dipaksakan untuk dibuka untuk umum terlebih dahulu. Hal ini berlaku khususnya untuk stasium I yang diketahui sebagai daerah kawasan sasi bagi masyarakat setempat. Oleh karena itu, cara pengaturan sasi sudah cukup baik, namun perlu diatur dan dimusyawarahkan kembali.

Peranan pemerintah dalam mendukung dan memberikan pendampingan kepada masyarakat juga akan sangat membantu dalam kelestarian jenis teripang di daerah ini. Dukungan pendampingan tentang informasi pentingnya peranan pantai dan keberadaan teripang akan membuka batasan pemahaman berbagai masyarakat di sekitar pantai yang memanfaatkan pantai sebagai sumber kehidupannya. Pemerintah melalui kegiatan CORMEP. Usaha yang sama juga ditujukan kepada pihak swasta yang dianggap konsisten mampu mendampingi masyarakat dan mengusahakan kelestarian keberadaan teripang.

\section{KESIMPULAN}

Keragaman jenis teripang di Perairan Pulau Auki Distrik Padaido Kabupaten Biak Numfor tergolong rendah, yang diketahui mempunyai 10 jenis. Indeks keragaman $\left(\mathrm{H}^{\prime}\right)$ pada stasiun I adalah 0,38 yang didominansi oleh jenis Holothuria scabra, stasiun II adalah 0 yang hanya dijumpai satu jenis yaitu Holothuria atra, sedangkan stasiun 3 adalah 0,42 yang didominansi oleh Bohadschia similis. Berbagai kegiatan masyarakat setempat sangat mempengaruhi tinggi rendahnya keragaman, termasuk aktivitas masyarakat yang memanfaatkan teripang.

\section{DAFTAR PUSTAKA}

Anomimous. 2003. Manfaat $\mathcal{E}$ perekonomian teripang. http:/ manfaat-perekonomian-teripang, diakses 05 september 2009.

Anomimous. 2008. Manfaat teripang gamat. http:/dombabunting. Blogspot.com/2009/05/manfaat - teripanggamat.htm!

Bengen, G.D., K. Maurice., K. Carla., T. Amiruddin., Dangeubun, dan O. Turbey. 2005. Profil Singkat Sumberdaya Pesisir Kepulauan Padaido Kabupaten Biak Numfor, Papua.

Fachrul, F, M. 2007. Metode Sampling Bioekologi. PT. Bumi Aksara. Jakarta.

Laksono, P. M.; Prasodjo, T.; Mustika, A. B.; Gunawan, dan Riomanda, T. 2001. Kepulauan Padaido Haruskah Habis Terkuras. KEHATI, PSAP- UGM, DAN RUMSRAM. Yogyakarta.

Lewaherilla, N., I. Marcela., A. Joselina., L. Jonas., and T. Wilson. 2009. Profil Destructive Fishing Kepulauan Padaido Kabupaten Biak Numfor. COREMAP Papua.

Martoyo, J; A. Nugroho., dan T. Winanto. 2007. Budi Daya Teripang. Penebar Swadaya. Jakarta.

Romumohtarto, K dan Juwana, S. 2004. Meroplanton Laut. Penerbit Djambatan. Jakarta.

Sutamin, 1993. Petunjuk Praktis Budidaya Teripang. Penerbit Kanisius. Yogyakarta.

Yusron dan Susetiono. 2010. Diversitas fauna ekhinodermata di Perairan Ternate-Maluku Utara. Oseanologi dan Limnologi di Indonesia. 36(3): 293-307.

Yusron, E. 2003. Beberapa catatan fauna echinodermata dari perairan teluk sekotong, Lombok Barat, Nusa Tenggara Barat. Prosiding Seminar Riptek Kelautan Nasional. Kerjasama UPT Baruna Jaya-ISOI. Jakarta, 30-31 Juli 2003.

Yusron, E. 2006. Ekhinodermata di perairan teluk saleh, Sumbawa, Nusa Tenggara Barat. Oseanologi dan Limnologi di Indonesia. $40: 43$ - 52.

Yusron, E. dan P. Widianwari. 2004. Struktur komunitas teripang (Holothuroidea) di beberapa perairan Pantai Kai Besar, Maluku Tenggara. Makara Sains. 8(1): 15-20.

Yusron, E. 2004. Sumberdaya teripang di Perairan Tanjung Pai Padaido Biak Numfor Papua. Makara Sains. 8(3): 123127. 